\title{
Length-Weight Relationships, Age and Growth, and Body Condition of the Spottail Shiner (Notropis hudsonius) (Clinton 1824) in the Western Basin of Lake Erie
}

\author{
ELIZABETH IGNASIAK', ZACHARY STEFFENSMEIER, ELLEN WARFIELD and FELICIA BRATTI, Franz T. Stone Laboratory, The \\ Ohio State University, Put-in-Bay, OH, USA, and THOMAS P. SIMON, School of Public and Environmental Affairs, Indiana \\ University, Bloomington, IN, USA.
}

ABSTRACT. Total length $\left(L_{T}\right)$ and standard length $\left(L_{S}\right)(\mathrm{mm})$ were compared to weight $M_{B}(g)$ in the Spottail Shiner, Notropis hudsonius (Clinton 1824), in the Western Basin of Lake Erie. Length and weight relationship ( $\mathrm{n}=529)$, lengthfrequency distribution, and sex ratio were evaluated for tributary habitats and compared to coastal habitats. The total population had a positive correlation between log normalized $L_{T}$ and $M_{B}\left(y=3.0902 x-5.2289, R^{2}=0.995\right)$ and a positive correlation between $L_{S}$ and $M_{B}\left(y=3.1397 x-5.0501, R^{2}=0.996\right)$. Male Spottail Shiner had a positive correlation between $\log$ normalized $L_{T}$ and $M_{B}\left(y=3.0984 x-5.2465, R^{2}=0.995,\right)$ and a significant positive correlation between log normalized standard length and body weight $\left(y=3.1551 x-5.0775, R^{2}=0.996\right)$. Female Spottail Shiner had a positive correlation between log normalized $L_{T}$ and $M_{B}\left(y=3.078 x-5.2034, R^{2}=0.993\right)$ and a positive correlation between log normalized $L_{S}$ and $M_{B}\left(y=3.1338 x-5.0393, R^{2}=0.996\right)$. Males and females were not significantly different in $L_{T}$ or $L_{S}(F-t e s t=1.020$, $\mathrm{df}=260,267, \mathrm{p}=0.437)$. Sex ratio was 1:1. Spottail Shiner exhibit indeterminate growth and did not exhibit gender influenced growth patterns. Tributary individuals were significantly smaller than coastal individuals ( $F$-test $=0.346$, $d f$ $=65,202, p=<0.001$ ). Male age I individuals ranged from $12-54 \mathrm{~mm}$, age II individuals ranged from 57-99 $\mathrm{mm}$, and age III individuals ranged from $99-132 \mathrm{~mm}$. Female Age I individuals ranged from 12-48 mm, age II individuals ranged from $53-102 \mathrm{~mm}$, and age III individuals ranged from $102-129 \mathrm{~mm}$.

\section{INTRODUCTION}

The family Cyprinidae consists of minnows and carp and is the largest family of freshwater fishes in the world (Nelson 2006). Minnows are essential to energy transfer from lower to upper trophic levels by converting nutrients from zooplankton and aquatic insects to the broader food web (Hartman et al. 1992). Understanding the rates of growth and relationships between weight and length are essential to life history and population age structure. Accurately modeling aquatic ecosystem function depends on information that can be acquired through simple and cost effective techniques (Froese 2006).

The Spottail Shiner, Notropis hudsonius is common along the Atlantic coast, from the Altamaha drainage in Georgia north to the Connecticut and Thames drainages, throughout most of the St. Lawrence and Great Lakes basin and southern part of the Hudson Bay, north and west throughout Canada to the western border of Alberta near the mouth of the Macken-

${ }^{1}$ Address correspondence to Elizabeth M. Ignasiak, 8427 Muirland Dr., Broadview Heights, OH 44147. Email: eignasiak@hotmail.com zie River (Scott and Crossman 1973; Lee et al. 1980; Page and Burr 1991). Within the United States, the range extends southeast from northeastern Montana, North Dakota, eastern South Dakota, to southern Illinois including Minnesota, Michigan, Iowa, northern Indiana, and northern Ohio (Trautman 1981; Becker 1983; Page and Burr 1991; Stauffer et al. 1995; Simon 2011).

This study investigated the relationship between length and weight in Spottail Shiner to understand growth patterns based on gender with respect to habitat. In addition, the sex ratio and length frequency distribution was used to predict age structure. Both length and weight relationships are useful in comparing different populations and evaluating ecological patterns. Lake Erie individuals were collected from coastal habitats in the Western Basin and were compared to tributary populations. The purpose of this study was to determine patterns in gender growth differences, and specific correlations between two measures of length (i.e., total length $\left[L_{T}\right]$ and standard length $\left.\left[L_{S}\right]\right)$ and weight $\left(M_{B}\right)$ based on gender. Differences in growth were assessed to find whether differences between Spottail Shiner populations 
in the Western Basin were associated with coastal habitats compared to tributary habitats. Lastly, the growth range and age structure of individuals from the Bass Islands were compared to other populations in the Great Lakes region.

\section{Study Area}

\section{MATERIALS AND METHODS}

The Laurentian Great Lakes encompass one-fifth of the available freshwater in the world (Steffen et al. 2014). Lake Erie is globally the tenth largest lake and stores about two percent of the total volume of all of the Great Lakes (FWPCA 1968; Munawar et al. 1999). Lake Erie is the shallowest, most southern, and the most productive of the Great Lakes (Michalak et al. 2013). It has three separate basins, the western, central, and eastern basins, with depth increasing in an easterly direction (FWPCA 1968). This study was conducted in the Western Basin near the Bass Island Archipelago (in the area contained within lat $41.737198 \mathrm{~N}$, lon $-82.877068 \mathrm{~W}$; lat $41.714358 \mathrm{~N}$, lon $-82.768781 \mathrm{~W}$; lat 41.583450 $\mathrm{N}$, lon $-82.889107 \mathrm{~W}$; and lat $41.591534 \mathrm{~N}$, lon $-82.825972 \mathrm{~W})$, which is comprised of 31 islands in Ottawa County, Ohio. The study area has five major tributaries that include the Maumee (lat 41.700961 N, lon $-83.413353 \mathrm{~W}$ ), Sandusky (lat 41.472058 $\mathrm{N}$, lon $-82.704037 \mathrm{~W}$ ), Huron (lat $41.394587 \mathrm{~N}$, lon $-82.552474 \mathrm{~W}$ ), Portage (lat $41.515670 \mathrm{~N}$, lon $-82.956786 \mathrm{~W}$ ), and Vermillion (lat $42.424544 \mathrm{~N}$, lon $-82.364765 \mathrm{~W})$ rivers.

\section{Field Methods}

All study data was collected in the Western Basin of Lake Erie during daylight hours using a variety of gears and techniques to reduce bias. Studies were collected for a variety of purposes as part of investigations of the Bass Island region. Individual Spottail Shiner were collected from coastal and tributary habitats. Individuals used in the current study were collected during ichthyological investigations primarily during the spawning season (June-July). Sex ratios, length-frequency distribution, and length and weight relationships were based on 529 individuals from tributary, coastal, and open water habitats. Lot collections are part of the permanent collection of the Museum of Biodiversity, F.T. Stone Laboratory, The Ohio State University and are housed at Gibraltar Island.

\section{Laboratory Methods}

Individual fish were randomly subsampled from site-specific collection lots and blotted dry to remove excess moisture prior to wet weighing using a Sartorius balance with a resolution of $1 \mu \mathrm{g}$ (Middleton et al. 2013). Residual weights were adjusted from the wet weight to provide $M_{B}$. Due to the precision of the balance used in the analysis, it was impractical to measure live individuals or to attempt to weigh fish in the field. Fish were anesthetized in MS222 and fixed in 10 percent formalin. Fish used in the laboratory analysis were soaked in water just prior to being measured. The relationship between freshly preserved individuals was tested to verify weight accuracy. Fish shrinkage was stable after seven days after which lengths and weights were measured. Shrinkage was less than five percent of the true weight of live individuals; however, it is recognized that data might not completely reflect the length-weight relationships of live individuals. Length and weight of all specimens had similar treatment, so it is assumed equal effects in specimen response based on preservation. Individuals were blotted dry, and then weighed using an analytical balance. Gender was determined using a Zeiss dissection microscope. Male genitals were elongate, tube-shaped and associated with modified scales and resided within a shallow trough just posterior the anus and anterior the anal fin origin, while the female genitals were broader at the base and narrow at the distal edge for egg deposition. Length measurements included standard length $\left(L_{S}\right)$ and total length $\left(L_{T}\right)$, which were measured using digital calipers to the nearest $0.01 \mathrm{~mm}$. The $L_{S}$ was measured from the tip of the snout, horizontally, to the posterior tip of the notochord at the hypural plate, while $L_{T}$ was measured from the tip of the snout, horizontally, to the tip of the depressed caudal fin (Hubbs et al. 2004). All measurements were based on the standard procedure described in Hubbs et al. (2004). Age groups of individual Spottail Shiner were determined using length frequency distribution analysis (Nielson and Johnson 1983).

\section{Statistics}

Log normalized length and weight were graphed using a best fit trend line and the results were evaluated using simple linear regression. To determine the role of sex and habitat in growth of Spottail Shiner, an Analysis of Covariance (ANCOVA) (STATISIT- 
ICA 11.0) was done to compare $M_{B}$ and length, i.e., $L_{S}$ and $L_{T}$, between males and females, and between tributary and coastal waters. Habitat class was assessed to determine size effect, by separating populations into tributary and coastal shoreline groups. An F-test was used to compare body weight $M_{B}$ and length $\left(L_{S}\right.$ and $\left.L_{T}\right)$ for males and females, between weight or length between males and females, or if there was a significant difference between the males in tributary compared to coastal habitats (Sokal and Rohlf 2011). Spottail Shiner age groups were determined by sex using length-frequency distribution analysis (Nielsen and Johnson 1983). A two-way Analysis of Variance (ANOVA) (Sokal and Rohlf 2011) was used to determine if there were significant differences in the size distributions of age class between males and females. A chi-squared test was used to determine if there was any significant difference in the sex ratio between males and females in the random subsample. A two-way Analysis of Variance (Ftest) was used to determine if there were significant differences in tributary males and females compared to coastal males and females.

\section{RESULTS}

Spottail Shiner populations from the coastal shorelines of Bass Islands, the open water of the Bass Islands, Portage River, and Terwilliger's Pond in the Western Basin of Lake Erie were studied to determine length-weight relationships $(\mathrm{n}=529)$. We examined 1556 individuals from 26 sites around the Western Basin (see Supplemental Materials for list of sites) of Lake Erie and 529 individuals were randomly subsampled based on coastal, open water, and tributary habitats. Spottail Shiner individuals from the Western Basin had a positive correlation between $\log$ normalized $L_{T}$ and $M_{B}\left(\mathrm{y}=3.0902 \mathrm{x}-5.2289, \mathrm{R}^{2}\right.$ $=0.995$, Fig. 1) and a positive correlation between $\log$ normalized $L_{S}$ and $M_{B}\left(\mathrm{y}=3.1397 \mathrm{x}-5.0501, \mathrm{R}^{2}\right.$ $=0.996$, Fig. 1).

Male individuals had a positive correlation between $\log$ normalized $L_{T}$ and $M_{B}\left(\mathrm{y}=3.0984 \mathrm{x}-5.2465, \mathrm{R}^{2}\right.$ $=0.995$, Fig. 1) and a significant positive correlation between $\log$ normalized $L_{S}$ and $M_{B}(\mathrm{y}=3.1551 \mathrm{x}-$ $5.0775, \mathrm{R}^{2}=0.996$, Fig. 1). Male individuals collected in tributaries had a positive correlation between $\log$ normalized $L_{T}$ and $M_{B}\left(\mathrm{y}=3.2211 \mathrm{x}-5.5001, \mathrm{R}^{2}\right.$ $=0.983$, Fig. 2) and a positive correlation between $\log$ normalized $L_{S}$ and $M_{B}\left(\mathrm{y}=3.1796 \mathrm{x}-5.1341, \mathrm{R}^{2}=\right.$ 0.988, Fig. 2). Male individuals collected in coastal water had a positive correlation between log normalized $L_{T}$ and $M_{B}\left(\mathrm{y}=3.1052 \mathrm{x}-5.2521, \mathrm{R}^{2}=0.995\right.$, Fig. 2 ) and a positive correlation between log normalized $L_{S}$ and $M_{B}\left(\mathrm{y}=3.16121 \mathrm{x}-5.0852, \mathrm{R}^{2}=0.996\right.$, Fig. 2$)$.

Female Spottail Shiner had a positive correlation between $\log$ normalized $L_{T}$ and $M_{B}(\mathrm{y}=3.078 \mathrm{x}-5.2034$, $\mathrm{R}^{2}=0.995$, Fig. 1) and a positive correlation between $\log$ normalized $L_{S}$ and $M_{B}\left(\mathrm{y}=3.1338 \mathrm{x}-5.0393, \mathrm{R}^{2}=\right.$ 0.996, Fig. 1). Female individuals collected in tributaries had a positive correlation between log normalized $L_{T}$ and $M_{B}\left(\mathrm{y}=3.0367 \mathrm{x}-5.1356, \mathrm{R}^{2}=0.966\right.$, Fig. $3)$ and a positive correlation between log normalized $L_{S}$ and $M_{B}\left(\mathrm{y}=3.1236 \mathrm{x}-5.028, \mathrm{R}^{2}=0.987\right.$, Fig. 3). Female individuals collected in coastal waters had a positive correlation between $\log$ normalized $L_{T}$ and $M_{B}\left(\mathrm{y}=3.08 \mathrm{x}-5.2055, \mathrm{R}^{2}=0.995\right.$, Fig. 3) and a positive correlation between $\log$ normalized $L_{S}$ and $M_{B}$ (y $=3.135 x-5.0402, R^{2}=0.997$, Fig. 3).

There was a stable sex ratio of 1:1 for males and females. Males were not significantly different compared to females for either $L_{T}$ or $L_{S}$ (F-test $=1.020$, df $=260,267, p$-value $=0.437)$. Male and female individuals did not have a significant difference in $M_{B}($ F-test $=1.067, \mathrm{df}=260,267, p$-value $=0.304)$. Tributary male individuals $L_{T}$ was significantly different from coastal water male $L_{T}$ (F-test $=0.347, \mathrm{df}=$ 64, 196, $p$-value $=<0.001$ ). Male Spottail Shiner in tributary areas had a significantly different $L_{S}$ compared to coastal water male Spottail Shiner (F-test = $0.361, \mathrm{df}=64,196, p$-value $=<0.001)$. Male Spottail Shiner $M_{B}$ in tributary areas was not significantly different from coastal water male $M_{B}$ (F-test $=0.784$, $\mathrm{df}=64,196, p$-value $=0.129)$. Tributary female individuals $L_{T}$ was significantly different from coastal water female $L_{T}($ F-test $=0.174, \mathrm{df}=33,225, p$-value $=<0.001)$. Female Spottail Shiner in tributary areas had a significantly different $L_{S}$ compared to coastal water female Spottail Shiner (F-test $=0.174, \mathrm{df}=33$, $225, p$-value $=<0.001)$. Female Spottail Shiner $M_{B}$ in tributary areas were significantly different from coastal water female $M_{B}$ (F-test $=0.239$, $\mathrm{df}=33$, 225 , $p$-value $=<0.001)$. Tributary individuals were significantly different than coastal individuals (F-test $=0.346, \mathrm{df}=65,202, \mathrm{p}=<0.001)$.

Length frequency distributions of males and females show the differences in $L_{T}$. Male age I individuals ranged from 12-54, age II individuals ranged from 57-99, and age III individuals ranged from 99132 (Fig. 4b). Female age I individuals ranged from 12-48, age II individuals ranged from 53-102, and 
age III individuals ranged from 102-129 (Fig. 4a). The tributary and coastal females had the same age classes as all females (Fig. 4c), while male coastal individuals had the same age classes as all males (Fig. 4d).

\section{DISCUSSION}

Carlander (1969) reviewed previous studies that analyzed the length and weight relationship of the Spottail Shiner. Populations in previous studies within the Midwestern United States included Ohio (Wells and House 1974; Trautman 1981), Iowa (McCann 1959), New York (Werner 1980), Pennsylvania (Cooper 1983), Minnesota (Carlander 1943; Smith and Kramer 1964), Michigan (Wells and House 1974), Maryland (Elser 1961), Virginia (Jenkins and Burkhead 1994), Wisconsin (Becker 1983), Alabama (Alabama Department of Conservation 1958), and Canada (Peer 1966; Scott and Crossman 1973). We compare our information to other Great Lakes and Midwestern North American populations (Table 1). No latitudinal gradient was observed within the range of Spottail Shiner, and a positive relationship was observed between age and weight (Carlander 1969; Wells and House 1974). Gender based differential growth was observed with females tending to be larger than males based on mean $L_{T}$ (Wells and House 1974). The positive regression analysis rela-

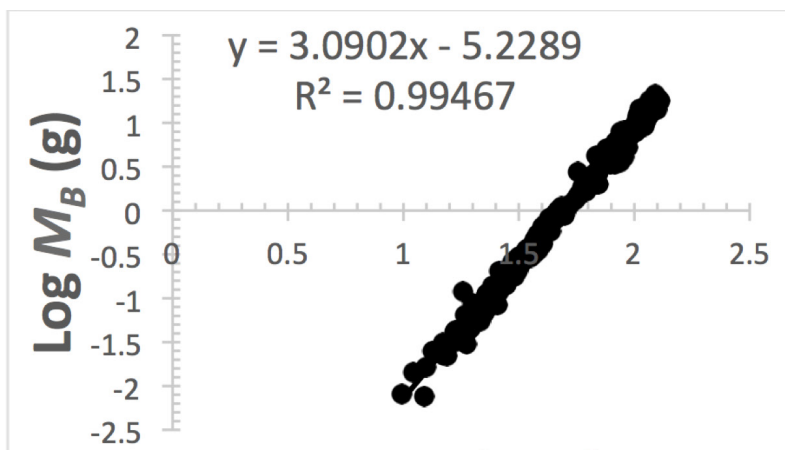

$\log L_{T}(\mathrm{~mm})$

A

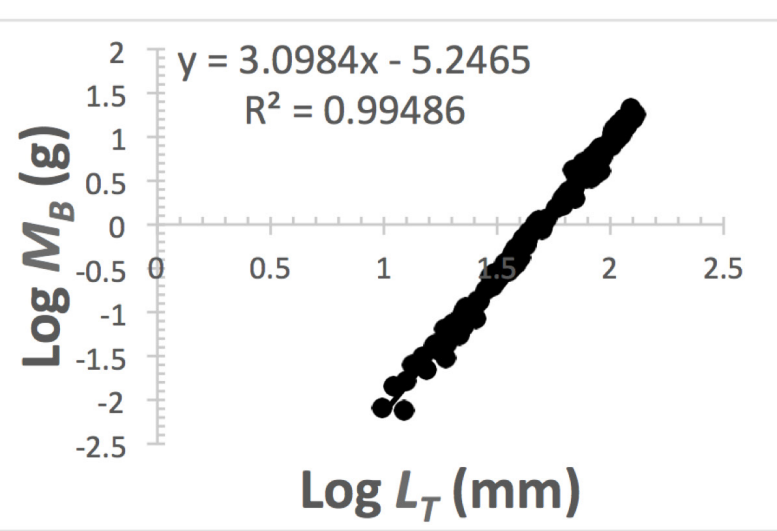

B

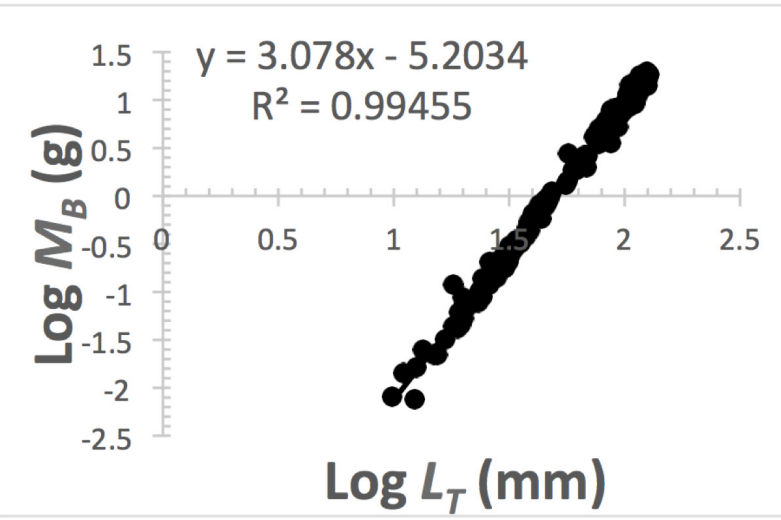

D
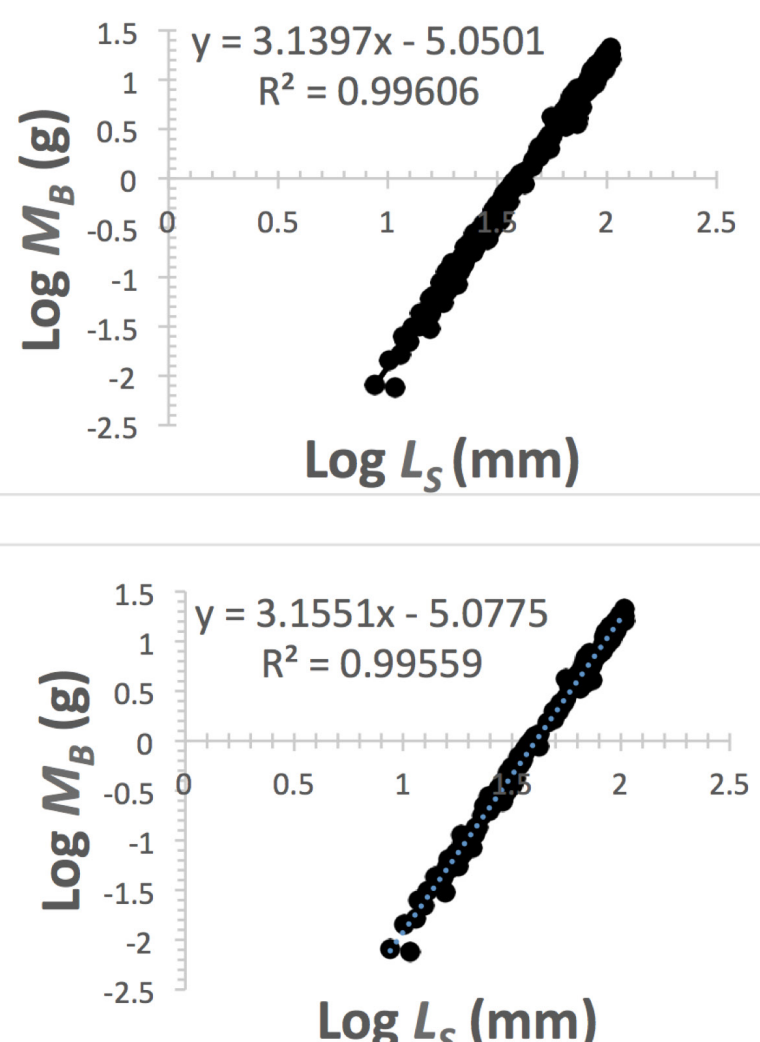

E

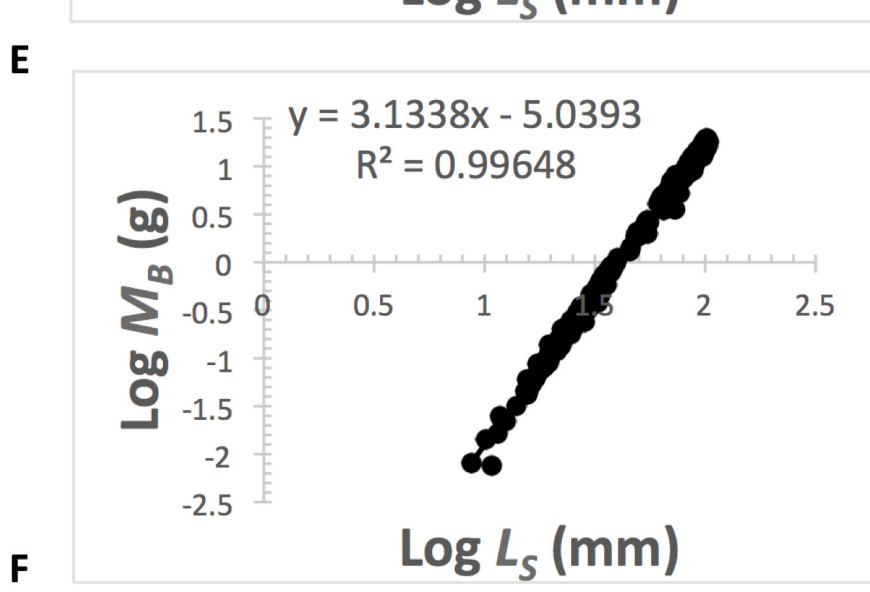

FIGURE 1. Log normalized length-weight relationship for Spottail Shiner (Notropis hudsonius). A. $L_{\uparrow}$ entire population ( $\mathrm{n}=529$ individuals), B. $L_{T}$ male $\left(n=268\right.$ individuals), C. $L_{T}$ female $(n=269)$, D. $L_{S}$ entire population $(n=529)$, E. $L_{S}$ male $(n=268)$, and F. $L_{S}$ female $(n=269)$. 


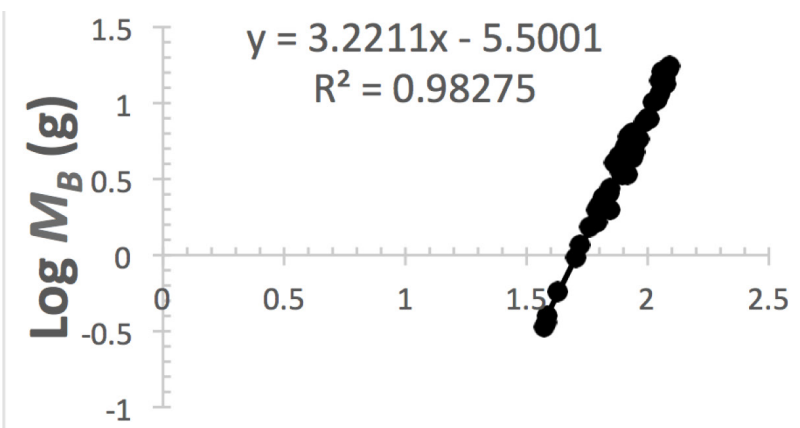

$\log L_{T}(\mathrm{~mm})$

A

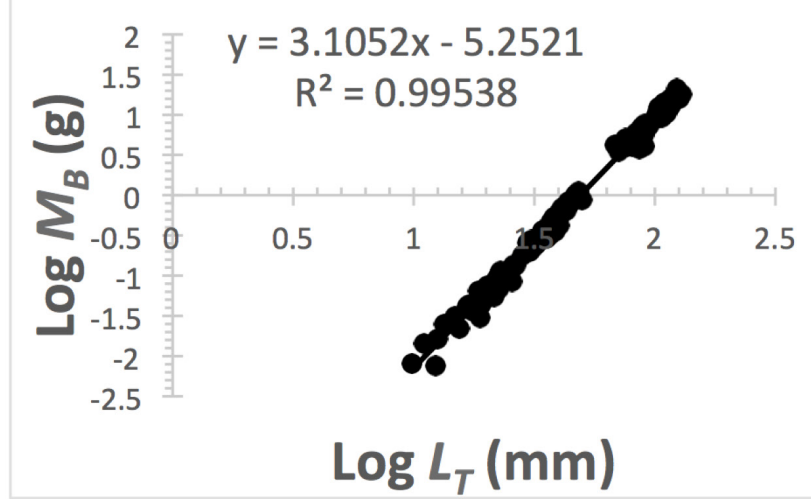

B

FIGURE 2. Log normalized length-weight relationship $(n=268)$ for male Spottail Shiner (Notropis hudsonius). A. tributary $L_{\text {, }}$ B. coastal water $L_{T}$, C. tributary $L_{S^{\prime}}$ and D. coastal water $L_{S}$.

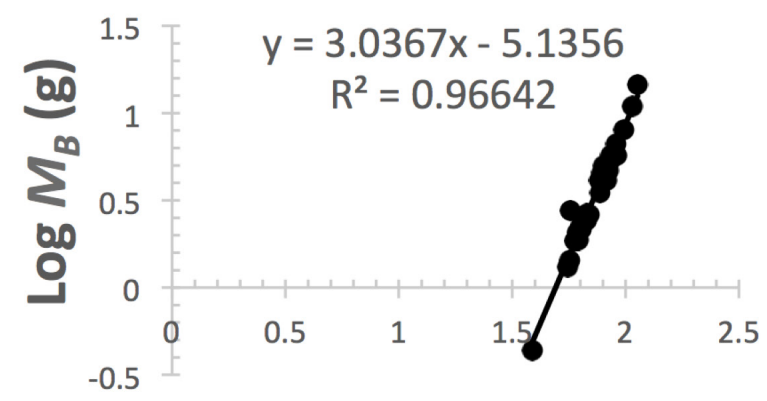

$\log L_{T}(\mathrm{~mm})$

A

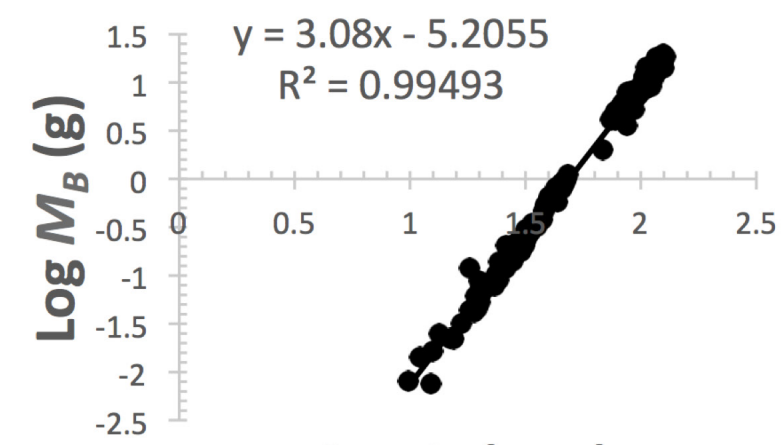

$\log L_{T}(\mathrm{~mm})$

B

FIGURE 3. Log normalized length-weight relationship $(n=269)$ for female Spottail Shiner (Notropis hudsonius). A. tributary $L_{T^{\prime}}$ B. coastal water $L_{T}$, C. tributary $L_{S^{\prime}}$ and D. coastal water $L_{S}$.

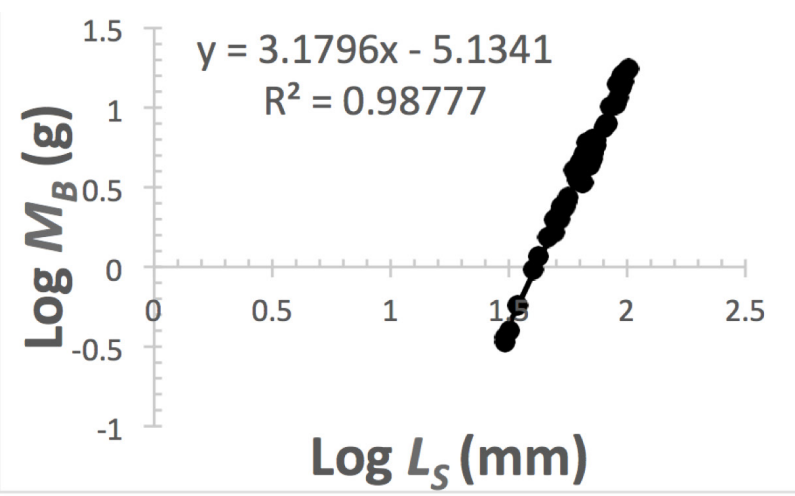

C

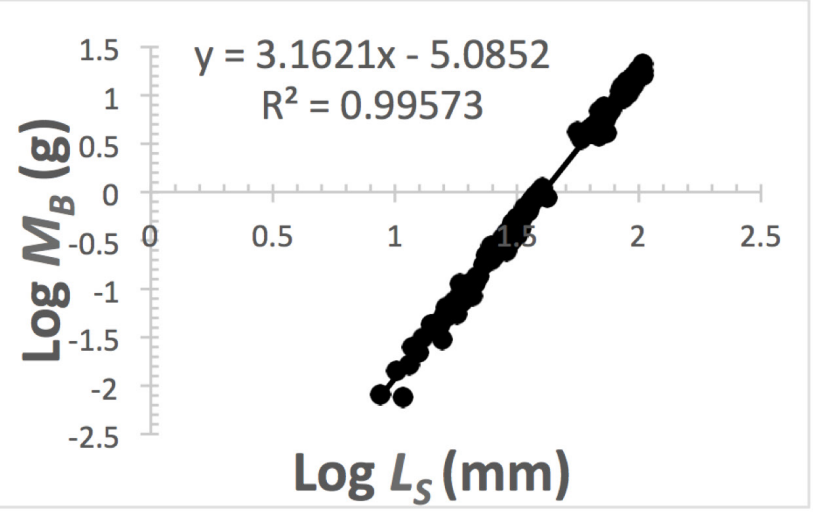

D

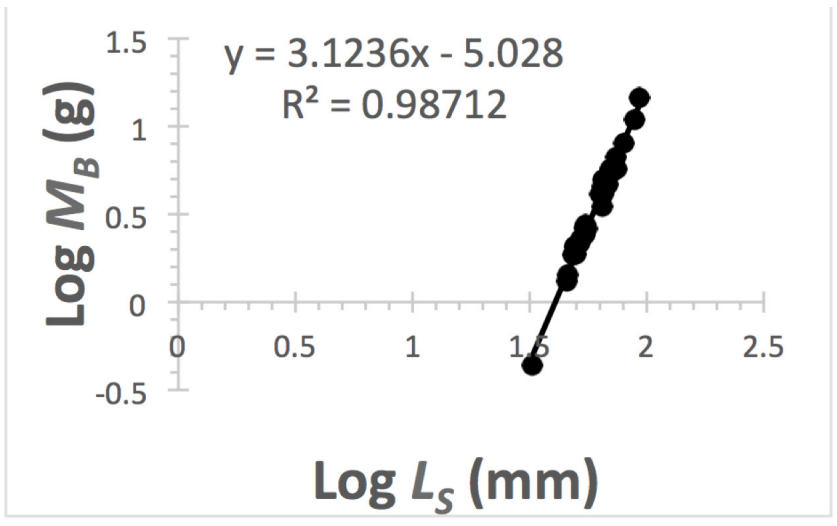

C

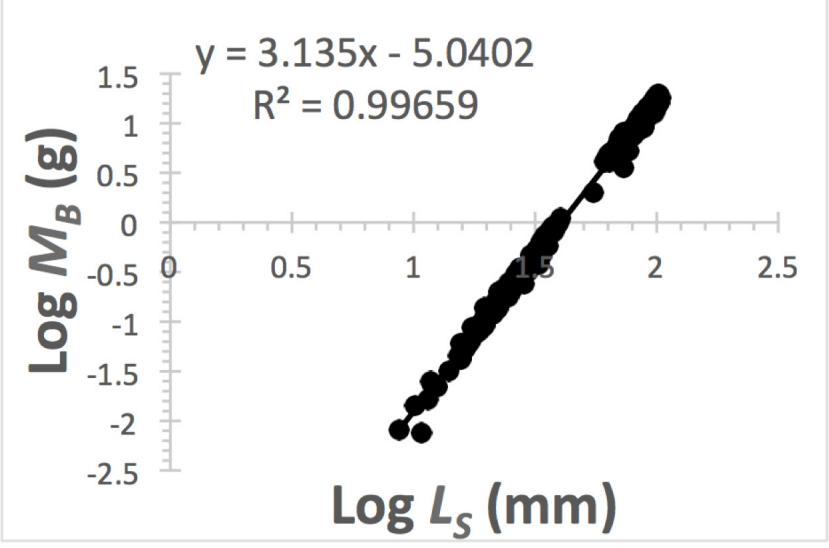

D 


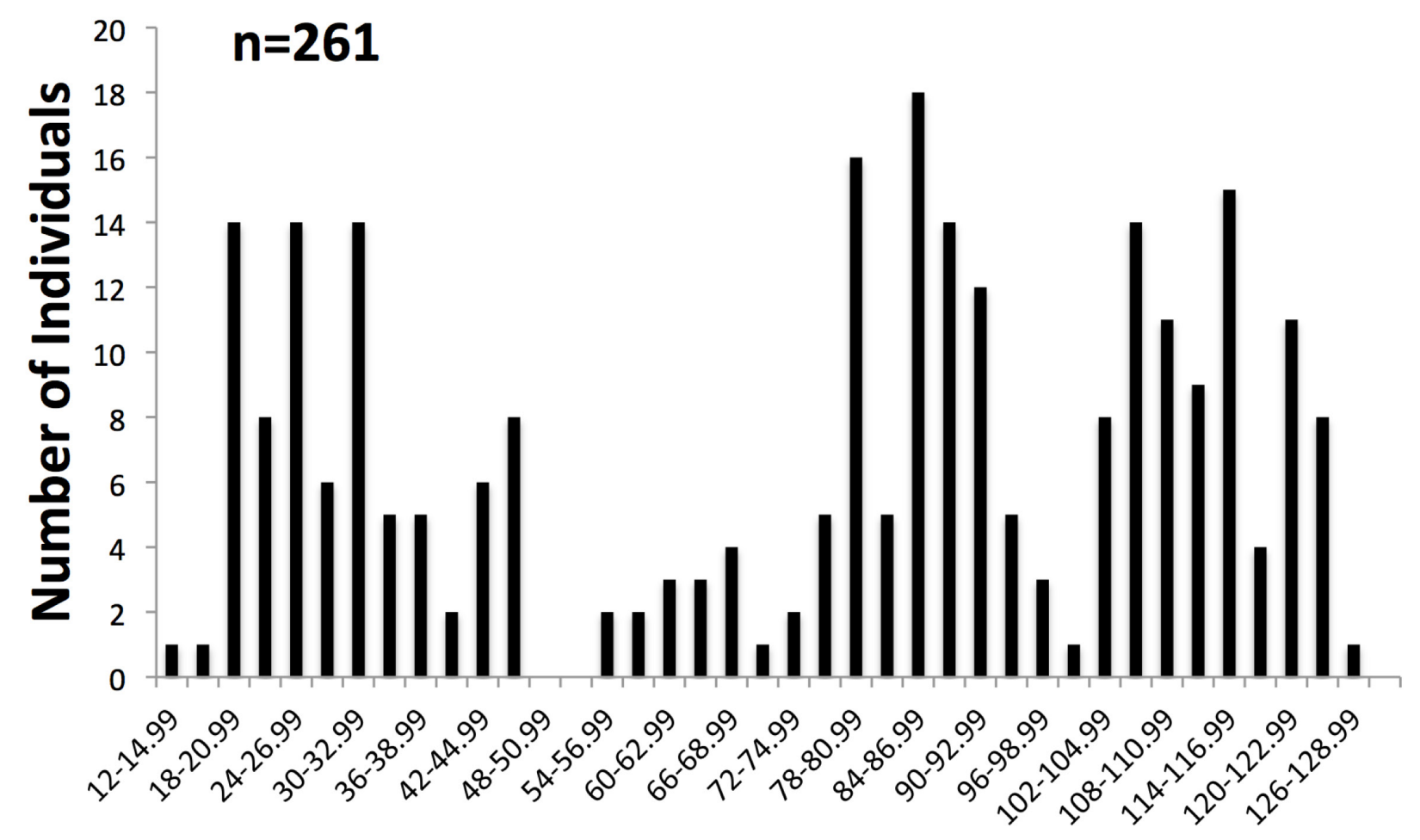

A

Length Interval (mm TL)

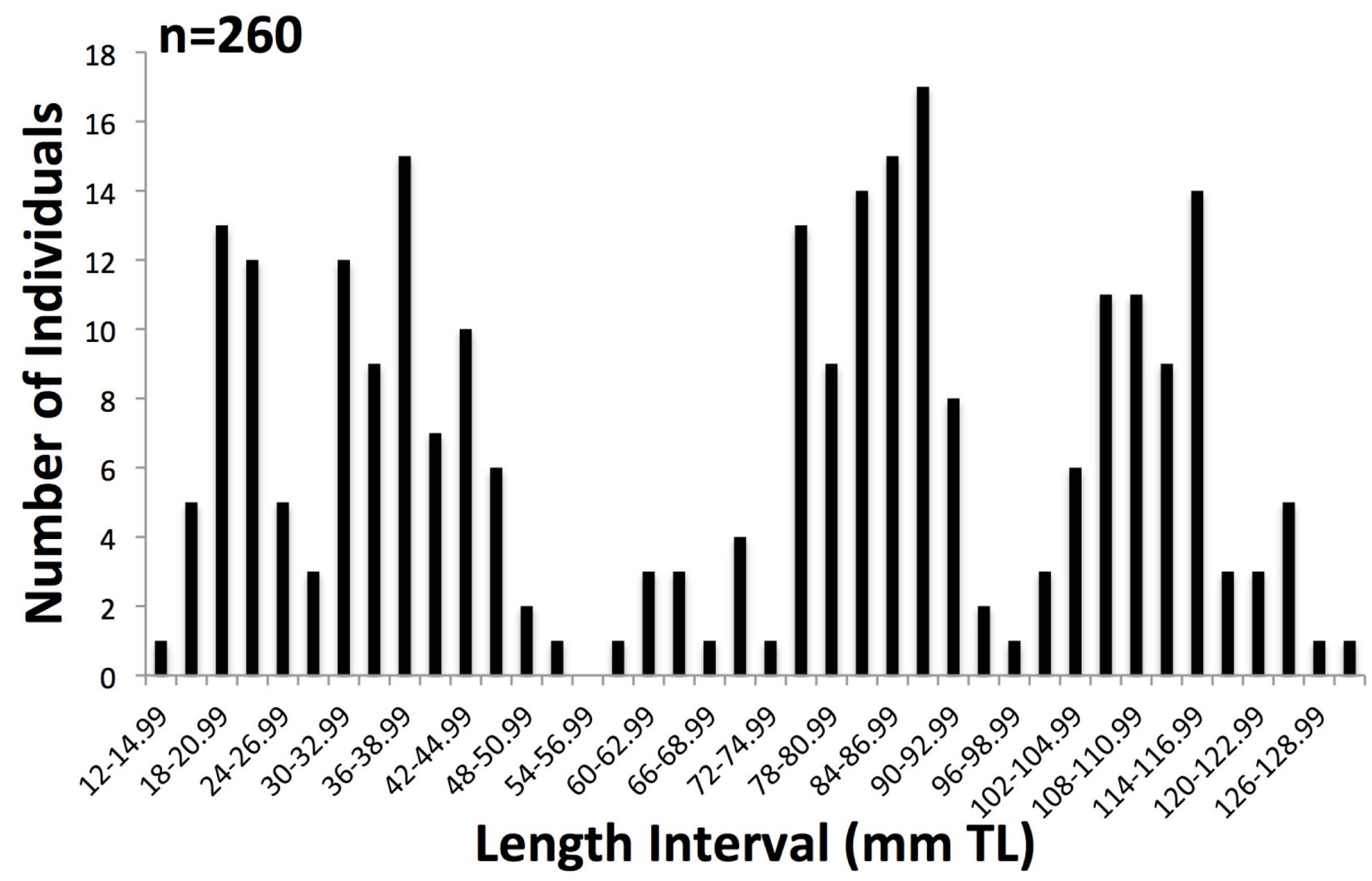

FIGURE 4, A \& B. Length frequency distribution of total length categories of Spottail Shiner individuals in the Bass Island area of Lake Erie. A. tributary female, B. tributary male. 


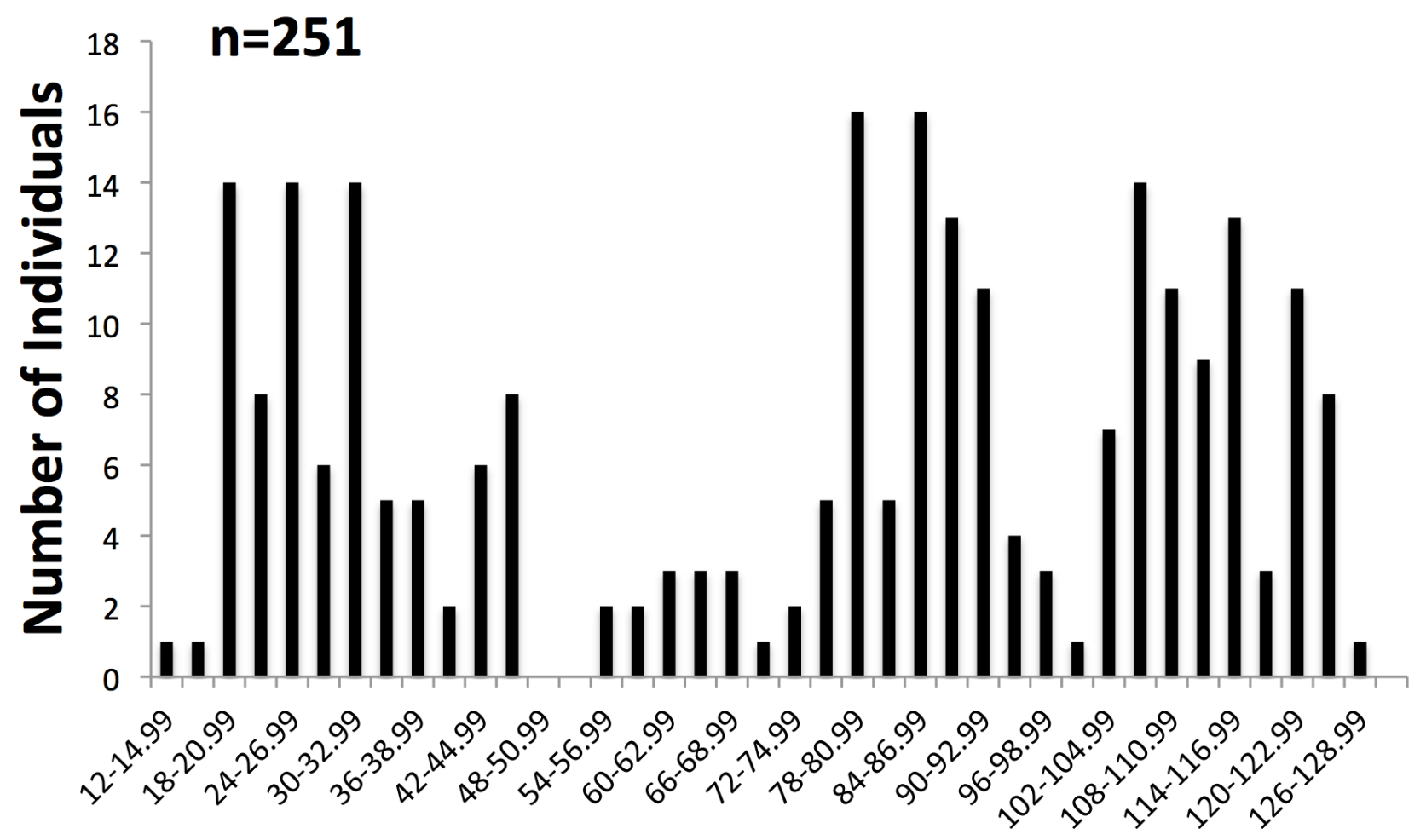

C

\section{Length Interval (mm TL)}

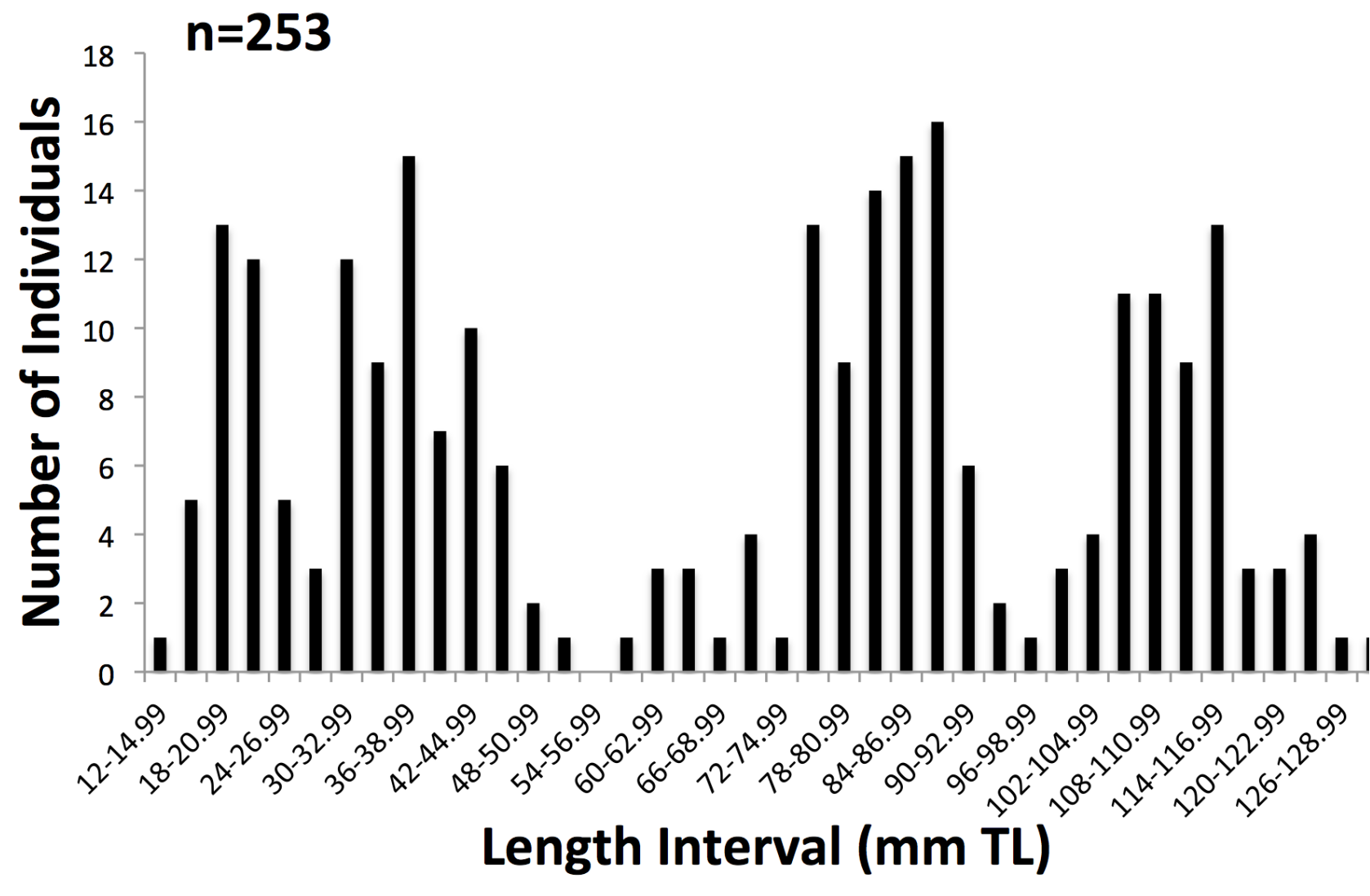

FIGURE 4, C \& D. Length frequency distribution of total length categories of Spottail Shiner individuals in the Bass Island area of Lake Erie. C. coastal water female, and D. coastal water male. 
Table 1

Comparison of Spottail Shiner age and growth relationships based on literature from the Great Lakes region and Midwestern United States

\begin{tabular}{lccccccc}
\hline \hline \multirow{2}{*}{ Location } & \multicolumn{6}{c}{ Mean LT Range (mm) } \\
\hline Canda (Saskatchewan) & Age 0 & Age I & Age II Age III Age IV Age V & Study \\
$\quad$ Nemeiben Lake & -- & 38 & 61 & 84 & -- & -- & Peer (1966) \\
Crooked Lake & -- & 46 & 69 & 91 & -- & -- & Peer (1966)
\end{tabular}

Iowa
Clear Lake
39.3
76.7
98.2107 .9
$--\quad--$
McCann (1959)

Michigan

Kalamazoo River

Wells and House (1974)

$\begin{array}{llllll}\text { Male } & -- & 54 & 79 & 93 & 106 \\ \text { Female } & - & 56 & 80 & 94 & 105\end{array}$

Lake Michigan

$\begin{array}{llllll}-- & 62 & 95 & 108 & 116 & 129\end{array}$

Female

$--\quad 63$

114

123

131

Minnesota (Statewide)

$$
23-51 \quad 41-66 \quad 64-84
$$

$84-94$

$--$

$-$

Lake of the Woods

$48 \quad 66 \quad 89$

$-$

Lower Red Lake

- Wells and House (1974)

Male

Female

-- 56

85

-- $\quad 58 \quad 90$

100

103

Female

Ohio (Statewide)

$$
\text { 51-76 64-84 -- }
$$

$106 \quad 113$

Lake Erie (Western Basin)

Trautman (1981)

$\begin{array}{lllll}\text { Male } & - & 76 & 101 & 125 \\ \text { Female } & -- & 78 & 108 & 135\end{array}$

Lake Erie, Bass Islands (July)

$\begin{array}{lllllll}\text { Male } & -- & 32 & 82 & 112 & -- & - \\ \text { Female } & -- & 30 & 82 & 114 & -- & -\end{array}$

Wisconsin

$--$ 
tionships of Spottail Shiner show that they exhibit indeterminate growth. Positive correlations exist between length and weight and show that a significant, positive relationship between age and length, as well as age and weight, existed for Western Basin Lake Erie populations. This is a similar result as reported by Wells and House (1974), which studied a Western Basin Lake Erie population near Sandusky.

Significant differences in $L_{T}$ and $M_{B}$ were not expected in tributary compared to coastal habitats. We hypothesized that due to lack of isolation from one another and ability to migrate freely that growth would not have been significantly different; however, F-test analyses found that there was a significant difference for males between tributary and coastal habitats. Females were expected to have increased weights compared to males due to the timing of the study; however, no difference in weight was exhibited. Spottail Shiner spawning occurs throughout its range throughout June and July (Becker 1983); therefore, females would be increasing in weight as vitellogenesis of ova occurs (Campbell and MacCrimmon 1970). Congruous with the preferred spawning habitat of Spottail Shiner includes bottom substrates composed of gravel and sand, which should have increased the likelihood of spawning males and large females being collected (Dickson 2008). Based on the $b$-factor in the logarithmic relationship between length and weight, Spottail Shiner individuals exhibited positive allometric growth. However, the $b$-value for females was lower. All age studies found that females were slightly larger than males, but were not significantly different in length of males and females, or in weights between males and females. Thus, female individuals were growing slightly faster in length than gaining weight. Potential explanations might be that the metabolic energy needed to yolk ova in females caused a decrease in expected weight. This pattern may be due to a lack of forage, or even density related feeding mechanisms caused by the large schools of individuals.

Bass Island region individuals exhibited less growth than statewide individuals during age I, but there was insufficient information for statewide comparison of individuals for ages II and III. Compared to other populations within the Spottail Shiner range, individuals in the Bass Island region of Lake Erie continue to show a trend of lower lengths at age I, but at ages II and III, the lengths are consistent with other areas within the range (Table 1).
The importance of understanding basic lengthweight, age and growth, and condition factors of members of the family Cyprinidae is critical for determining the trophic structure of a dynamic system, such as Lake Erie. Although population dynamics of cyprinids have not been well studied, the high economic significance of a balanced minnow foundation in the food web is critical for stability in the Western Basin (Hubbs et al. 2004). Spottail Shiner populations may reflect changing conditions and can serve as an early warning indicator of Lake Erie fish assemblage stability. They are extremely important commercially since they support a large baitfish industry and can serve as a dominant food source for top predator, whole body carnivores (Hubbs et al. 2004). Changing conditions in the Spottail Shiner population may reflect future large-scale effects potentially caused by hypoxia, climate change, or harmful algal blooms (Munawar et al. 1999; Michalak et al. 2013).

\section{SUPPLEMENTAL MATERIALS Specimens examined}

OHIO: Ottawa Co. Lake Erie, Schoolhouse Bay, off Lutz Point, Trawl \#2, Middle Bass Island, Put-in-Bay Twp., 41.0114403N $-82.7845333 \mathrm{~W}$, VII:8:2011, TP Simon \& EEOB 621 (N = 1 [1]); Lake Erie, $1.3 \mathrm{~km}$ off Catawba Island, ODNR Trawl \#021, Catawba Island, Put-In-Bay Twp., 41.5602000N -82.8557000W, VI:27:2011, TP Simon \& EEOB 621 ( $\mathrm{N}=5$ [5]); Lake Erie, Fox's Marsh, Middle Bass Island, Put-In-Bay Twp., 41.2866700N -82.6426000W, VII:7:2003, CL Smith, D Kane, and EEOB 621, ( $\mathrm{N}=17$ [17]); Lake Erie, Honey Point, North Bass Island, Put-In-Bay Twp., 41.3022700N -82.3431810W, VII:29:2011, TP Simon \& EEOB $621(\mathrm{~N}=41[41])$; Lake Erie, Schoolhouse Bay, off Lutz Point, Trawl \#2, Middle Bass Island, Put-In-Bay Twp., 41.6856333N -82.7847667W, VII:8:2011, TP Simon \& EEOB 621 ( $\mathrm{N}=3$ [3]); Lake Erie, East Pointe, $2.5 \mathrm{mi}$ E Put-In-Bay Twp., 41.6653700N -82.7964000W, VII:25:2014, TP Simon \& EEOB $5930(\mathrm{~N}=13[13])$; Lake Erie, Northeast Beach, 0.6 mi N Put-In-Bay, Gibraltar Island, 41.6584580N -82.8191030W, VI:262015, TP Simon \& EEOB5930 ( $\mathrm{N}=1$ [1]); Lake Erie, Perry Monument Beach, $0.5 \mathrm{mi}$ E Put in Bay, South Bass Island, Put-In-Bay Twp. 41.6527660N -82.8126230W, VI:24:2015, TP Simon \& EEOB5930 ( $\mathrm{N}=165$ [156]); Terwilliger's Pond, Bayview Avenue, 0.3 mi W Put-In-Bay, South Bass Island, Put-In-Bay 
Twp., 41.6566500N -82.8269550W, VI:25:1966, MB Trautman ( $\mathrm{N}=13$ [13]); Lake Erie, Schoolhouse Bay Trawl, Middle Bass Island, Put-In-Bay Twp., 41.6950000N -82.7963330W, VII:9:2010, TP Simon \& EEOB 621 ( $\mathrm{N}=5[1])$; Lake Erie, Perry Monument Beach, 0.1 mi NW Put-In-Bay, South Bass Island, 41.2866700N -82.6426000W, VI:29:1992, TM Berra \& EEOB 621 ( $\mathrm{N}=18[18]$ ); Lake Erie, South Bass State Park, 2 mi S Put-In-Bay, South Bass Island, Put-In-Bay Twp., 41.6432760N -82.8377550W, VI:24:2015, TP Simon \& EEOB 5930 ( $\mathrm{N}=12$ [11]); Lake Erie, Alligator Bar, SW Gibraltar Island, South Bass Island, Put-In-Bay Twp., 41.6573148N -82.8229398W, VII:2:2010, TP Simon \& EEOB 621 ( $\mathrm{N}=1[1])$; Lake Erie, Schoolhouse Bay, Mid-bay Trawl, Middle Bass Island, Put-In-Bay Twp., 41.6867167N -82.7963167W, VII:9:2010, TP Simon \& EEOB $621(\mathrm{~N}=2[2])$; Lake Erie, East Pointe Beach, $1.2 \mathrm{mi}$ E Put-In-Bay, South Bass Island, Put-In-Bay Twp., 41.6656130N -82.7958310W, VI:24:2015, TP Simon \& EEOB 5930 ( $\mathrm{N}=40[37])$; Lake Erie, Manilla Bay, North Bass Island, Put-In-Bay Twp., 41.7128310N -82.8308130W, VIII:31:1967, MB Trautman (N = 620 [67]); Lake Erie, Put-In-Bay, South Bass Island, Put-In-Bay Twp., 41.6558280N -82.8245020W, VII:1:1987, Ross ( $\mathrm{N}=55$ [27]); Lake Erie, Schoolhouse Bay, Mid-bay trawl, Middle Bass Island, Put-In-Bay Twp., 41.6886167N -82.7844500W, VII:9:2010, TP Simon \& EEOB 621 ( $=5$ [5]); Portage River, OH SR 51 Bridge, Elmore, Elmore Twp., 41.6562660N -82.8272260W, VI:27:1980, Ross ( $\mathrm{N}=13$ [13]); Lake Erie, East North Bass Island, Put-In-Bay Twp., 41.2809000N -82.1699100W, VII:5:2004, N Ultrup ( $\mathrm{N}=203$ [36]); Lake Erie, Fox's Marsh, North Bass Island, Put-In-Bay Twp., $41.7119444 \mathrm{~N}-82.8319444 \mathrm{~W}$, VII:8:2002, CL Smith and EEOB 621 ( $\mathrm{N}=4$ [4]); Lake Erie, SE Shore to East Pointe, North Bass Island, Put-In-Bay Twp., 41.7075640N -82.8105000W, VII:12:2010, TP Simon \& EEOB 621 ( $\mathrm{N}=1$ [1]); Portage River, $\mathrm{OH}$ SR 51 Bridge, Elmore, Elmore Twp., 41.4766600N -82.9532000W, VII:7:2011, TP Simon \& EEOB 621 ( $\mathrm{N}=1$ [1]); Terwilliger's Pond, Bayview Avenue, $0.2 \mathrm{mi}$ W Put-In-Bay, South Bass Island, Put-In-Bay Twp., 41.6562660N -82.8272260W, VII:8:2011, TP Simon \& EEOB 621 ( $\mathrm{N}=3$ [2]); Lake Erie (N = 21 [21]); Lake Erie, South Bass Island, Put-In-Bay Twp., VI:23:1966, Ichthyology Class ( $\mathrm{N}=292$ [32]).

\section{ACKNOWLEDGMENTS}

This study was supported by The Ohio State University, Franz T. Stone Laboratory, Ohio Sea Grant, The Thomas Langlois foundation, and The Friends of Stone Lab through generous donation.

\section{LITERATURE CITED}

Alabama Department of Conservation.1958. Report for fiscal year, October 1, 1956-September 30, 1957. 200 p.

Becker GC. 1983. Fishes of Wisconsin. Madison (WI): The University of Wisconsin Press. 1052 p.

Campbell JS, MacCrimmon HR. 1970. Biology of emerald shiner Notropis athernoides Rafinesque in Lake Simcoe, Canada. J. Fish Biol. 2(3):259-273. https://doi. org/10.1111/j.1095-8649.1970.tb03284.x

Carlander KC. 1943. Growth rate of the spottail minnow, Notropis hudsonius (Clinton), in Minnesota waters. Minnesota Bureau of Fisheries Research Investigation Report 50: 1-3.

Carlander KD. 1967. Handbook of Freshwater Fishery Biology. Volume 1. Ames (IA): Iowa State University Press. 752 pp.

Cooper, EL. 1983. Fishes of Pennsylvania. State College (PA): The Pennsylvania State University. 252 p.

Dickson T. 2008. The Great Minnesota Fish Book. Minneapolis (MN): The University of Minnesota Press. 232 p.

Elser HJ. 1961. Recorded Maryland fish. Maryland Conservation 38(2):15-17.

Federal Water Pollution Control Administration (FWPCA). 1968. Lake Erie Environmental Summary 1963-1964. Cleveland $(\mathrm{OH})$ : Department of Interior, Federal Water Pollution Control Administration, Great Lakes Basin Commission.

Froese R. 2006. Cube law, condition factor and weight-length relationships: history, meta-analysis and recommendations. J. Appl. Ichthyol. 22(4):241-253. https://doi.org/10.1111/ j.1439-0426.2006.00805.x

Hartman KJ, Vondracek B, Parrish DL, Muth KM. 1992. Diets of emerald shiners and Spottail Shiners and potential interactions with other western Lake Erie planktivorous fishes. Journal of Great Lakes Research 18(1):43-50. https://doi. org/10.1016/S0380-1330(92)71273-8

Hubbs CL, Lagler KF, Smith GR. 2004. Fishes of the Great Lakes Region. 3rd edition. Ann Arbor (MI): University of Michigan Press. 90 p. https://doi.org/10.3998/mpub. 17658

Jenkins RE, Burkhead NM. 1994. The Freshwater Fishes of Virginia. Bethesda (MD): American Fisheries Society. 1079 p.

Lee DS, Gilbert CR, Hoctt CH, Jenkins RE, McAllister DE, Stauffer JR Jr. 1980. Atlas of North American Freshwater Fishes. North Carolina State Museum of Natural History, Publication 1980-12.

McCann, JA. 1959. Life history studies of the Spottail Shiner of Clear Lake, Iowa, with particular reference to some sampling problems. Transactions of the American Fishery Society, 88(4):336-343. https://doi.org/10.1577/15488659(1959)88[336:LHSOTS]2.0.CO;2

Michalak AM, Anderson EJ, Beletsky D, Boland S, Bosch NS, Bridgeman TB, Chaffin JD, Chog K, Confesor R, Daloğlu I, et al. 2013. Record-setting algal bloom in Lake Erie caused by agricultural and meteorological trends consistent with expected future conditions. PNAS 110(16):64486452. https://doi.org/10.1073/pnas. 1216006110

Middleton S, Perello M, Simon TP. 2013. Length-weight re- 
lationships of the mimic shiner Notropis volucellus (Cope $1865)$ in the Western Basin of Lake Erie. Ohio J.of Sci. $112(2): 44-50$.

Munawar M, Edsall T, Munawar IF, editors. 1999. State of Lake Erie: Past, Present, and Future. Ecovision World Monograph Series. Leiden (The Netherlands): Backhuys Publishers. 500 p.

Nielsen LA, Johnson DL. 1983. Fisheries Techniques. Bethesda (MD): American Fisheries Society. 468 p.

Nelson JS. 2006. Fishes of the World. 4th ed. Hoboken (NJ): John Wiley and Sons, Inc. 601 p.

Page LM, Burr BM. 1991. Freshwater Fishes. New York: Houghton Mifflin Company. 432 p.

Peer DL. 1966. Relationship between size and maturity in the spot-tail shiner, Notropis hudsonius. J. of the Fisheries Res. Board of Can. 23:455-7. https://doi.org/10.1139/f66-035

Scott WB, Crossman EJ. 1973. Freshwater Fishes of Canada. Bulletin 184. Ottawa (Canada): Fisheries Research Board of Canada. 966 p.

Simon, TP. 2011. Fishes of Indiana: A Field Guide. Bloomington (IN): Indiana University Press. 368 p.

Smith LL Jr, Kramer RH. 1964. The Spottail Shiner in Lower Red Lake, Minnesota. Trans. of the American Fisheries Soc. 93:35-45. https://doi.org/10.1577/15488659(1964)93[35:TSSILR]2.0.CO;2
Sokal RR, Rohlf FJ. 2011. Biometry: The Principles and Practice of Statistics in Biological Research. 3rd ed. New York: W.H. Freeman. 887 p.

Stauffer JR, Botz JM, White LR. 1995. The Fishes of West Virginia. University Park (PA): The Pennsylvania State University.

Steffen MM, Belisle BS, Watson SB, Boyer GL, Wilhelm SW. 2014. Status, causes and controls of cyanobacterial blooms in Lake Erie. J. of Great Lakes Res. 40(2):215-225. https:// doi.org/10.1016/j.jglr.2013.12.012

Trautman MB. 1981. The Fishes of Ohio. Columbus (OH): The Ohio State University Press. 782 p.

Wells L, House R. 1974. Life history of the Spottail Shiner (Notropis hudsonius) in southeastern Lake Michigan, the Kalamazoo River and western Lake Erie. U.S. Bur. of Sport Fisheries and Wildlife Res. Report No. 20. 55 pp.

Werner, RG. 1980. Freshwater Fishes of New York State, A Field Guide. Syracuse (NY): Syracuse University Press. 186 p. 